\title{
Virtual Environment for Autism. Drawing Space for Connection and Inclusion: an Open Debate
}

\author{
Anna Lisa Pecora
}

\section{Abstract}

The use of Virtual Reality (VR) in special education is still at an experimental stage, therefore it is important to test and explore many features of this technology. For this reason, it represents a growing sector of studies raising in research and debates. The sense of optimism, which encourages the experiments about ICT for Autistic disorder, is driven by some positive results of the experiences using $\mathrm{VR}$, since those applications are showing the potential for education and rehabilitation in cognitive disorder. In this context, the ICAR 17 disciplines embody the multidisciplinary connective texture to investigate, read and understand the drawing space in order to become a knowledge medium for ADS people and their achieving to cultural contents. The present paper looks back to previous researches to compare different opinions and, in conclusion, to consider potentials and opportunities of this field of studies. Otherwise, analyzing publications about VR and autism, it stands out the lack of reference to perceptual contents and about the way they can influence the knowledge process. My attempt will not be only a comparison between different opinions about the use of immersive technology for autism, but also trying to fill in some of the details regarding spatial representation (when documents allow) related to their perceptual resonance.

Keywords

representation, Virtual Reality (VR), Virtual Environment (VE), Autism (ASD), learning.

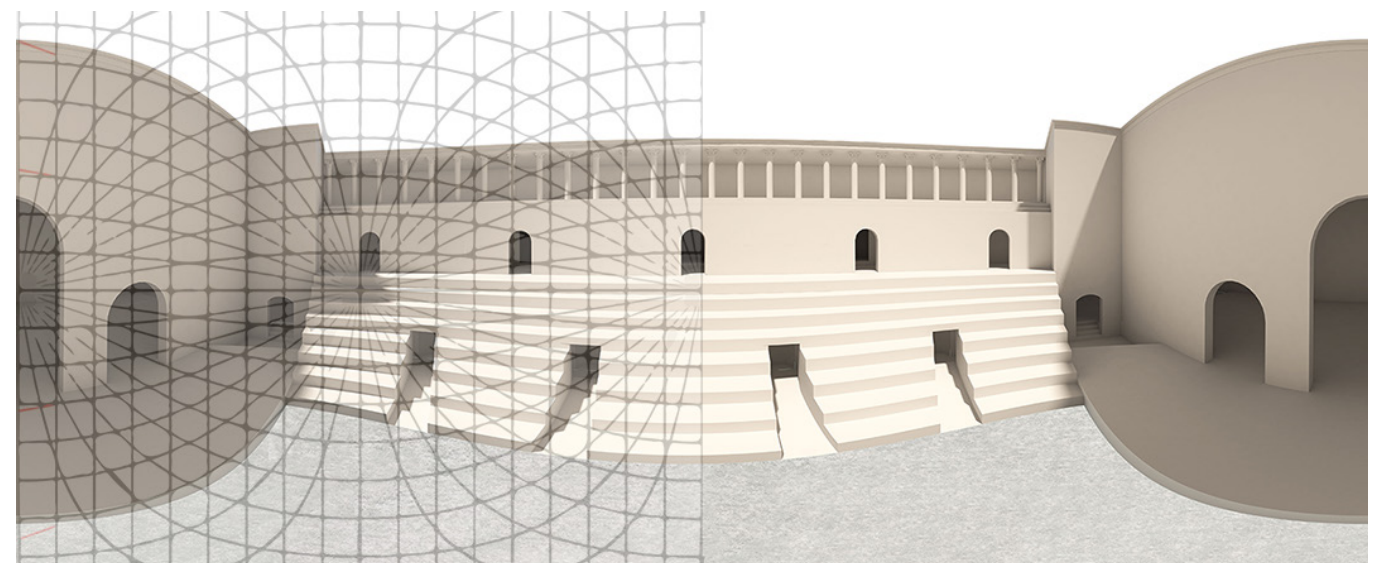


We often talk about inclusion, but hosting disability is not enough in order to allow everybody to gain the same knowledge targets and the same approach to the surrounding environment. Notably, the interaction with the environment, in cognitive disabilities, may assume a specific rule to enhance social and cultural skills involving perceptual stimuli. Romano Del Nord, talking about interaction between autism and architecture, claims: "Since the fact that the environment $[\ldots]$ generates sensitivities to the organs of perception has now been universally acquired and shared, we cannot help but consider, in planning decisions, aspects that go beyond the pure and simple 'spatial functionality' and that involve the disciplines of proxemics, interpersonal visual communication as well as psychology and environmental psychology" [Del Nord 20I0, p. 5]. In the recent years the representation disciplines, supported by the widespread of new technologies progress, play a fundamental role in the interdisciplinary mediation of educational field. If drawing has the potential of a language, at the same time universal but also specific in the message translation, the ICT can be a versatile instrument to control various communicative levels adapting itself to personal user needs. Referring to Hermelin and $O^{\prime} C o n n o r$ studies, the difficulties involving the autistic clinical frame are connected especially to perception deficiency, with effects similar to blind people [Bogdashina 20 15]. Frequently, visual distortions lead impairment in deep sense perception, diplopia, changes in shapes, dimensions and movements. VR system gives the opportunity to customize visual framework, acting on tools related to each of these aspects, becoming a valid support, for people with ASD, in understanding physical space. Referring to the first experiments in 1993 by Chen and Bernard-Optis, the first evidence is the capability of stimulating attention and focusing on information trough an appealing instrument, raising emotional involvement and, therefore, with new potentiality in educational training. It's a considerable benefit, for people with languages impairment, because the stimulus can be conveyed on figurative instead of verbal contents, modifying the cognitive dynamics. But, since the perceptual system in ASD react to different stimuli than neurotypical, the design of VE must be properly set up, considering the atypical answer concerning relation between vision and motion. Despite the visual system is not impairment in autism, the perceptual incoherence leads to a sensorial agnosia that inhibits the ability to confrere the right semantic meaning to environment figurative signs [Bogdashina 20 I5]. In addition, problems with proprioceptors can complicate the understanding of space dimensions and relations between objects, space and body [Williams, 1994]. All these aspects must be considered in designing virtual environment that integrate the vision perceptual modalities with the motion apparatus. In fact, the virtual navigation system is based on 360 degrees pictures (renderings, photos or videos) and, as soon as the limits of the observed image exceed the human visual field, the experience involves the body motion (even if just for rotating the head) turning from a static view to a dynamic perspective [Rossi et al. 20 19]. Usually this relation helps the knowledge of the space features, while in autism it can create confusion or stress caused by a disorder of the 'efferent copy' phase [Russell 1994]. In this cases, to enhance wayfinding, navigation and understanding surround world, the VE must be structured considering speci-

Fig. I.VIRART's experiment. Image of the Virtua Environment. Photo published in Cobb Sue Valerie Gray, 2007.Virtual Environments Supporting Learning and Communication in Special Needs Education. Top Lang Disorders. No. 3, 2007, Vol. 27, pp. $21 \mid-225$; a) VIRART (1995). Frame of the virtual ski slope from the user's point of view;

b) Anna Lisa Pecora Schara. depth clues and target elements.

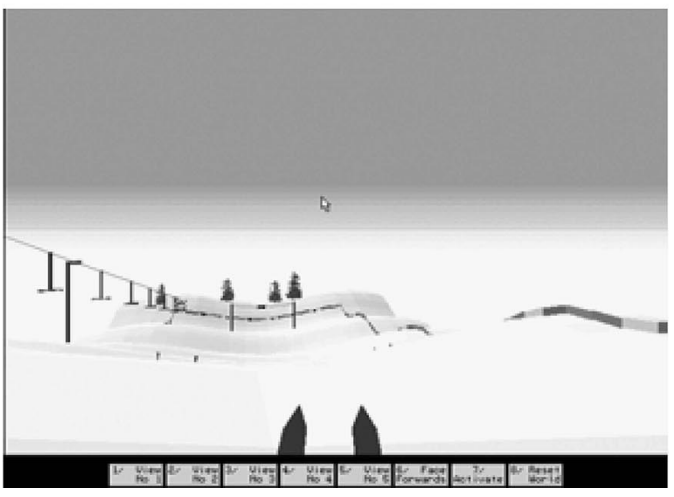

Scheme with the main depth clues

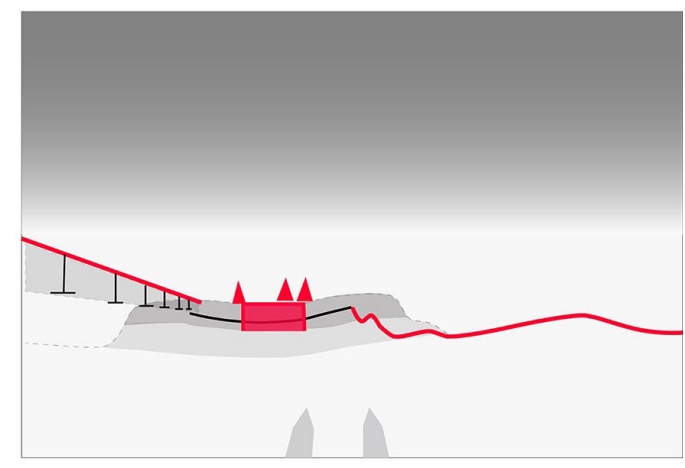


fic issues as: minimal distraction [Chen Li, 20 I8], simple visual patterns and colors [Strickland 1997; Saiano 20 I5], visual guide for motion and clear spatial reference [Mostafa 20 I 4] concerning distances, positions and deep effects. However, it is difficult to set general guidelines because of the variety of behavioral difference between autistic users. For example, an Italian research of Genoa University exploring the effectiveness of VE in special education, confirms that people with ASD easily learn actions triggered by simple color stimuli [Saiano 20 I 5] but, at the same time, a visual target can become a distraction from the main goal due to a long eye gaze fixation [Wade 20 15].Therefore, it's important to provide visual guidelines without triggering overstimulation. Referring to this aspect, an example is one of the first experiments led by Sue Cobb and the VIRART team. There are no descriptions about the virtual environment, but watching the published photo, it is possible to deduce some visual aspects interfering in the perceptual process. The VE represents a ski slope characterized by simple framework where objects have basic geometries easily recognizable (fig. I). The highly prevalent white produces a flat configuration where it's difficult to understand the perspective. For this reason, the use of some graphic depth cues is crucial: a curb on the right and a schematic ski lift on the left side, provide two linear clues that, converging toward the frame center, become an important depth gradient. In fact, the angle of graphic signs on the vertical and horizontal axis, is a key element for tridimensional perception [Arnheim 1997]. The distances and dimensions reduction of ski-lift elements offer others depth gradients in the observed image; acting in the same direction, they enhance each other because "the more the gradient is regular, the stronger their effect acts" [Arnheim 1997, p. 227]. Moreover, the motion target, represented by the finish area, is emphasized with different graphic solutions (an horizontal line, some trees, a strong shade) representing a slope visual closure. In addition, the visual frame allows the view of the tip of the skis. This is another important detail enhancing embodiment and wayfounding because it gives a cue on self position and direction motion in the virtual space. As I introduced, the issues connected to the motion modalities involve many crucial aspects in our topic. Holden, Almeida, Park, Lewis, Griffin introduce the problem of cybersickness [Ravasio 20I I]. Related to this point, there are many doubts: For example Park [Park et al. 20 I7], Almeida [Almeida et al. 2017] and Reiners [Reiners et al. 2014] reported high levels cybersickness in their HMD studies. Similarly, Bashiri [Bashiri et al. 2017] suggest that: "studies have indicated that cybersickness is a barrier to the use of training or rehabilitation tools in virtual reality environments" and

Fig. 2. Josman's experiment. Image of the Virtual Environment. Photo published in:Josman, Weiss 2008.

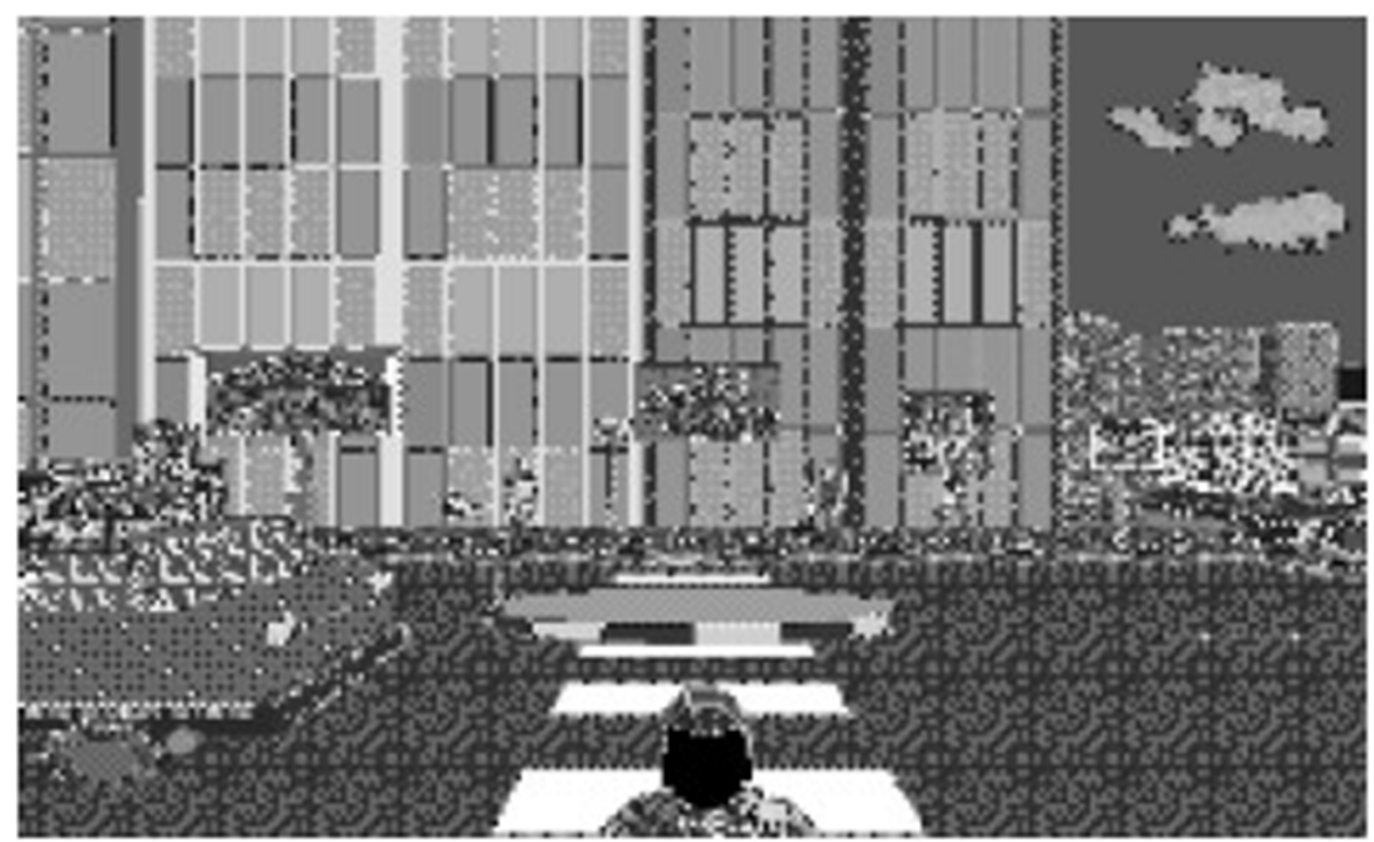


Polcar and Horejsi [Polcar, Horejsi 20 15] reported that when present, cybersickness influenced learner attitudes towards technology negatively" [Bradley, Newbutt 20 I8, p. 6]. The symptoms, as well as the seasickness (oculomotor disorders, neurovegetative problems, vestibular disorders) are usually related to the period of the experience and to the age of the users, with more effect on women. In Ravasio opinion, the cybersickness is due to an incongruence between the movements perceived by the eyes and the information caught by the body and therefore: "between visual information indicating body movement and the proprioceptive and kinaesthetic vestibular information suggesting a static position" [Ravasio $20 \mathrm{I}$, p. 65]. Such discomforts are also related to software and hardware [Newbutt et al. 2020], in fact they decrease when the high quality of devices allows adjusting the focal distance in relation to the individual interpupillary distance [Newbutt et al., 20 I 6]. In 20 I 8, the University of Camerino leads a research on neurotypical people to test the developing of motion sickness during virtual navigation. They understand that the modality of interaction

Fig. 3. Example of a rendering 360 degrees Draft of a video related to a starting research about an autism friendly virtual archeological tour. The image represents the first step of a progressive building transformation over the centuries (graphic elaboration by Anna Lisa Pecora).

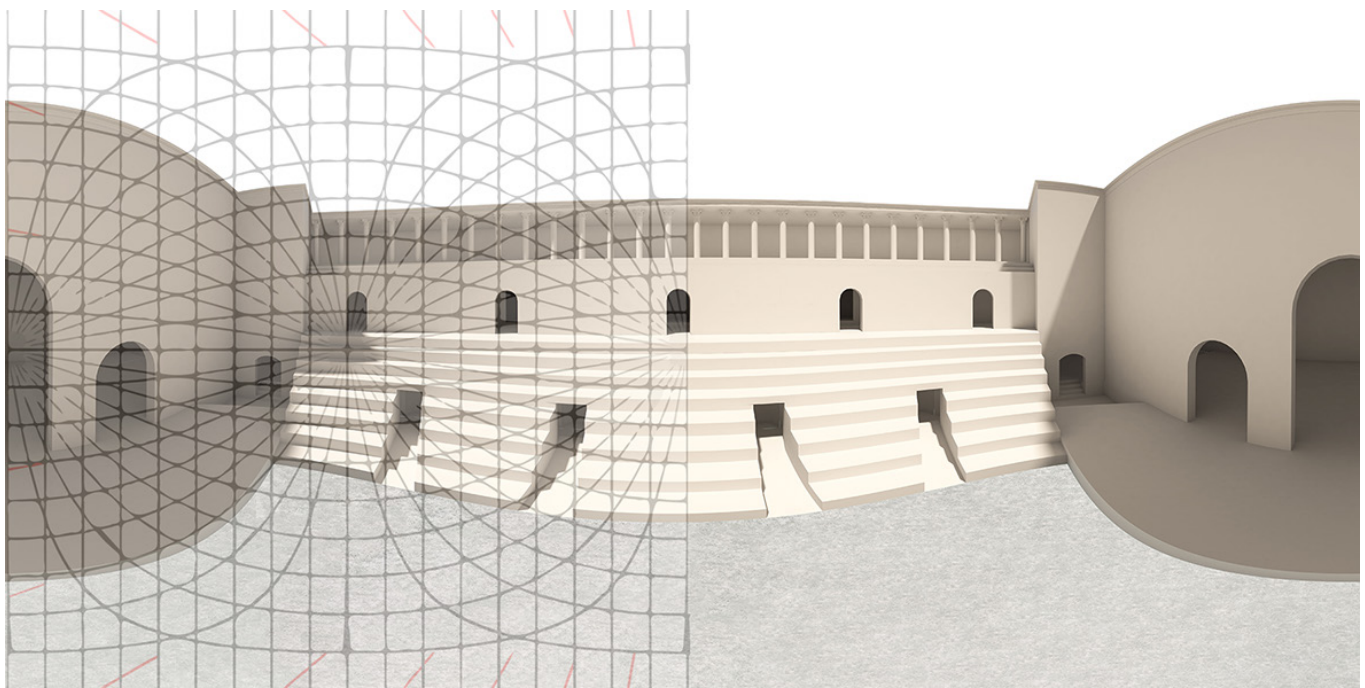

with the environment can influence the sense of motion sickness [Rossi, Olivieri 2019]. So that, the continuous navigation, even if supports the understanding of the virtual space, at the same time it occurs a longer detachment between visual and body stimuli raising the discomfort. At the opposite, the Point and Teleport exploration removes these problems but complicates the wayfounding and the memory of the environment, particularly for beginners or people with cognitive impairment. Moreover, the low resolution or the lack of ambient light can increase the sense of tiredness and visual fatigue interfering in performances. For example, an experiment lead by the University of Israel in 2008, with an old technology (a Pentium 3), reported some difficulties in understanding the virtual environment and its operation. Here, the pixels size is too large to define the graphic elements in the scene, thus, they work like visual distraction more than like uniform coatings. For the same reason, the object borders and different surfaces are not recognizable, complicating the perception of the three-dimension; this way the represented space appears flat, lacking in effective depth cues, without visual hierarchies and, therefore, sensorial confused (fig. 2). As Arnheim explains: "the whole layout is unreadable, because each possible relation is soon broken by a contrary and non-describable action. [...] The result is confusion" [Arnheim 1994, p. 194]. Rather, if customized on specific user's need, the representation path allows the process of synthesis, communication and explicitation of the physical space necessary for decoding and subsequent learning its cultural contents. This is the attempt of a starting research lead by 
the Federico II University, focused on the so called Sepolcro di Agrippina in the Campi Flegrei archeological site (figs. 3-4). The future research will attempt to produce an autism friendly virtual tour showing the progressive structural transformation of the theatre building and how its relationship with the coastline changed throughout history. The short video in VR will act as a sensorial medium between the ASD user and the final in vivo tour. In particular way, the virtual space has the important role to decode with a simple and schematic graphic language, the complex theoretical and morphological contents of the real architecture. This way, the drawing shows relations between different elements that, only through their figurative configuration, can be understood thanks to graphic choices. Setting the detail level, the chromatic and luminous qualities, the quantity and the value of graphic signs in the VE, are essential features to define the sense of immersion and presence and therefore the communicative power driven by perceptual inputs. This way, the consciousness of living a

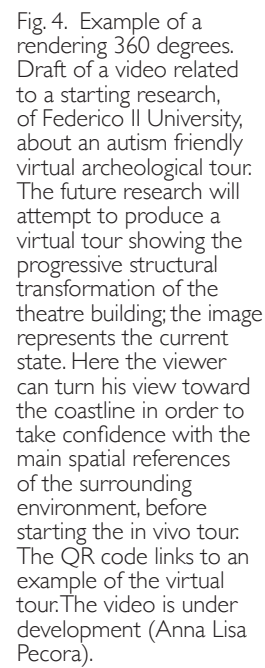

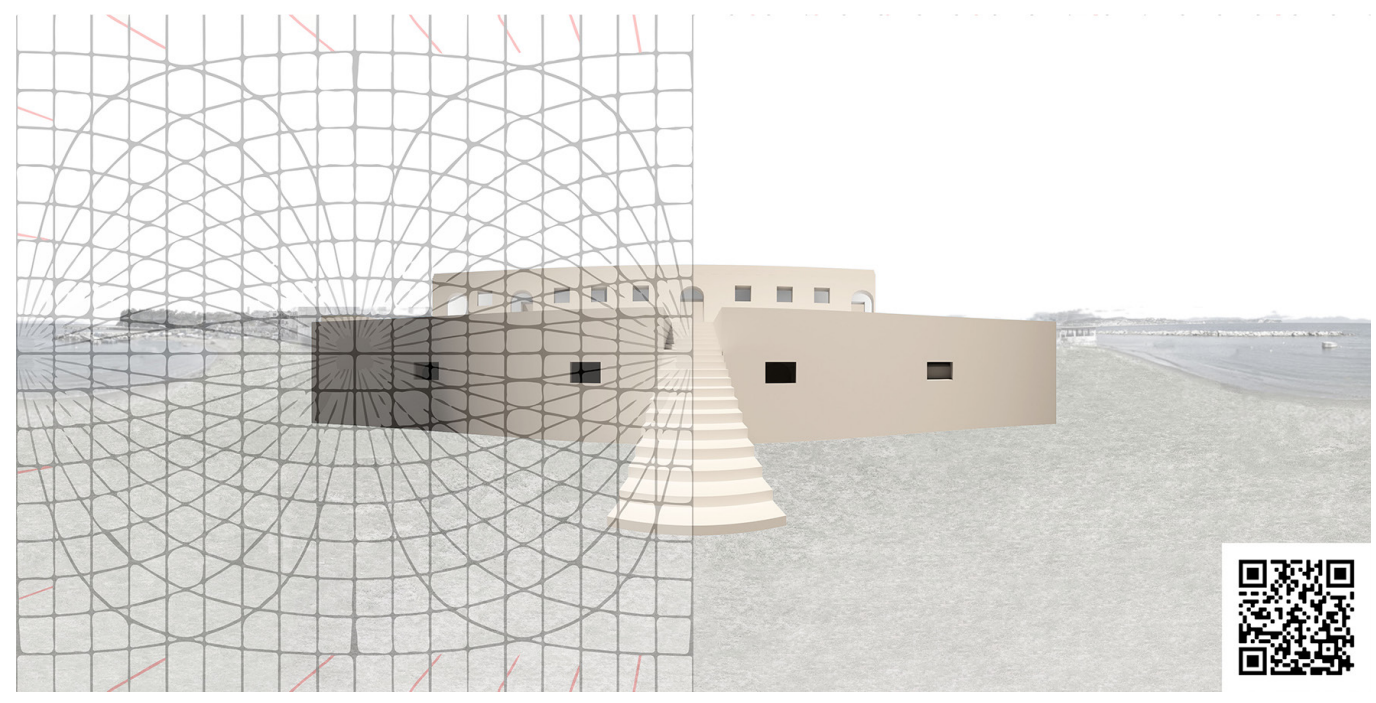

virtual condition with the same perceptions of real life can be a support to transfer life skills and to improve autonomy of the ASD people more effectively than in real experiences. In fact, the sense of security given by the consciousness of living a space without dangers, removes the frequently unlikely symptoms occurring during unknown experience, as, for example, anxiety and stress [Gorini et al. 2008; Freeman et al. 2017], point out on the safe condition of the virtual environment "where consequences are not real" [Gorini et al. 2008, p. 5]. Usually, neurotypical children raise their knowledge trough experiments, training, errors, while students with autism use to avoid these experiences because they could be dangerous or frightening, since their impairment of sensorial system and low proprioceptive awareness. In 1996 Strickland publishes one of the first immersive experiments using an RV-HMD with the aim of teaching autistic children how to across a street alone. The experiment relevance lays on two main aspects: on one hand, it puts in evidence how the miscommunication with ASD can affect the data result, on the other hand it shows the potential of a safe environment providing the user, sense of comfort and safety. For this reason: "The virtual world was a simplified street scene consisting of a sidewalk and textured building shapes. All motion objects such as people, animals, and objects in the sky were removed. Periodically one car, whose speed could be changed, would pass the child standing on a sidewalk. The contrast was kept low in the scenes with gray being the dominant color. The low quality of the headset screens provided a less detailed environment automatically. The cars, the focal point of the test, were presented in bright, contrasting colors [...] red and blue" [Strickland, 1997, p. 4]. Only later, another visual stimulus is introduced: a stop sign is moved to different parts of the tracking area during the later tests and the children are asked to 
Fig. 5. Dorothy Strickland's experiment (1997). Image of the Virtual Environment
graphical schemes A) Dorothy Strickland (1997). Street scene of the Srtickland's experiment. http://www.virtualgalen.com/virtualhealing/ autism.htm

B) Scheme with the main depth clues (Anna Lisa Pecora)

C) Scheme with the main target elem the highlighted in red (Anna Lisa Pecora).
Fig. 6. Strickland's experiment. Image of the Virtua Environment. Photo by Dorothy Strickland from: Dorothy Strickland from: com/virtive ing/autism. htm>.

find it and stopping there (figs. 5, 6). In this kind of configuration, the environment works like a neutral background helping to focus on visual targets, otherwise the oversimplification of morphological spatial signs creates difficulties in evaluating distances. For example, in the last exercise: "it was difficult to judge the sign's distance because of the lack of comparison cues" [Strickland 1997, p. 4]. Here, the graphical elements of the VE, are characterized by linear continuity: the sidewalk, the road, the long buildings sequence; so that, even if they contribute to perspective vision and to the dept sense they don't provide a taxonomy of the space elements neither a visual pattern helping the understanding of mutual object location. The depth effects depend by physiological qualities as well as by some perceptual gradients related to shapes, colors, dimensions, motion, recorded by the retina [Arnheim 1997]. The more these characters are explicit and the stronger the space structure is understood. So, the Strickland's experiment is useful to analyze visual aspects in order to understand how they can influence the space perception in autistic people, but also the potential of VR as learning environment for special education. It opens the way to many other studies that, for over 25 years, have extended the fields of observation, the technologies employed and the behavioral target for treatments. "Whilst there has been some progress in testing the relevance and applicability of VR for children on the autism spectrum in educational contexts, there remains a significant challenge in developing robust and usable technologies that can really make a difference in real world" [Parsons 2017 p. 356]

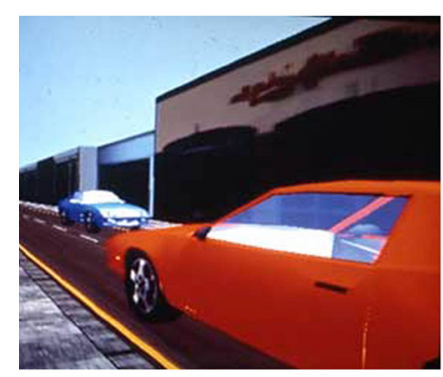

B

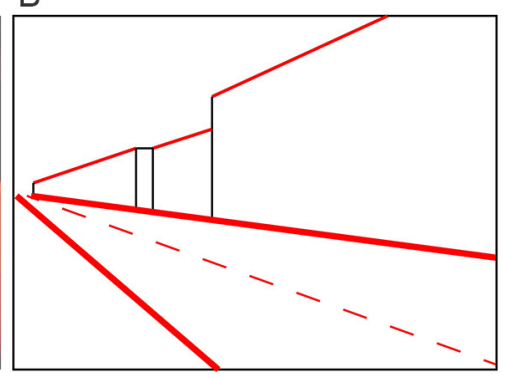

C

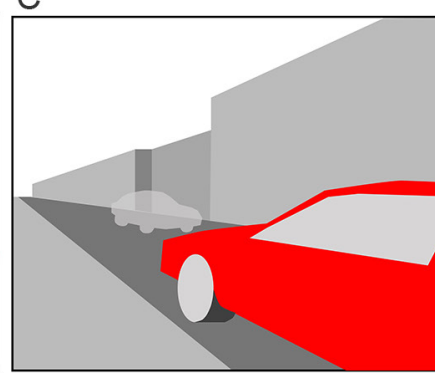

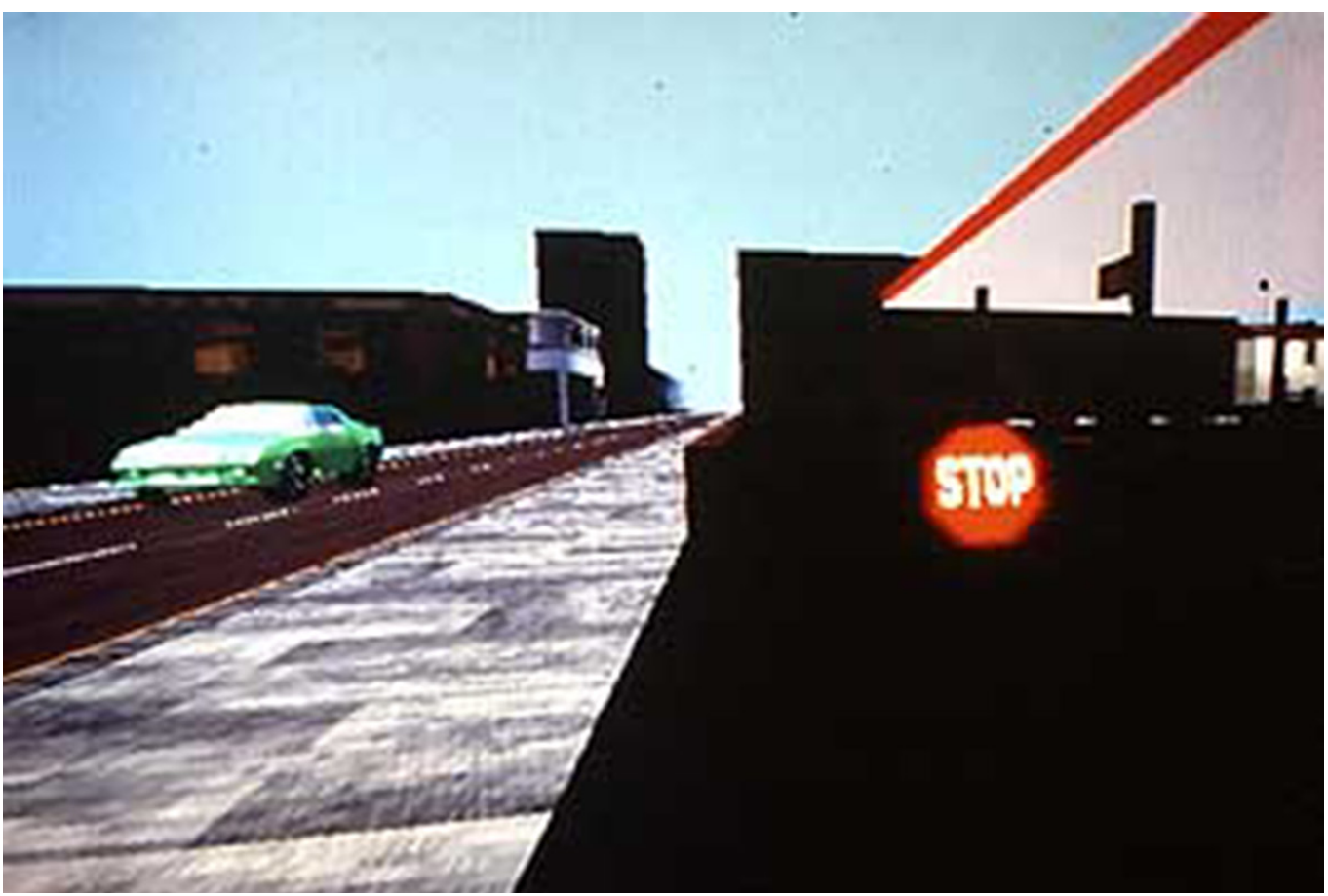




\section{Conclusions}

The range of disciplines and technologies engaged in studies about autism and VR, show an increased interest and potential of this issue with a growing interdisciplinary approach, but without the contribute of representation disciplines. For the sake of narration, we are unable to argue here about a broader series of the experiments observed, which are therefore summarized in the attached table. In the taxonomy of data, priority has been given to the aspects of spatial figuration, although the publications rarely describe details of the settings. They often remain vague about some aspects useful to understand the perceptive response to the stimulus coming from the designed space. In spite of difficulties given by the atypical response of autism and by communication impairment, the studies have claimed that virtual reality can provide a valid support in special education, creating mental bridges between individual perceptual world and real scenarios. Referring to specific autistic frame, related to perception impairment, we suggest a need of investigating about customized technologies. Particularly, trough the specific intervention of drawing disciplines, actually lacking, it would be possible to fill the gap between the VR design and the cognitive reaction to visual stimuli, providing a relevant effect on cultural and social inclusion.

\section{Acknowledgement}

Thanks to Caterina Borrelli for the 3D model of the so called Sepolcro di Agrippina.

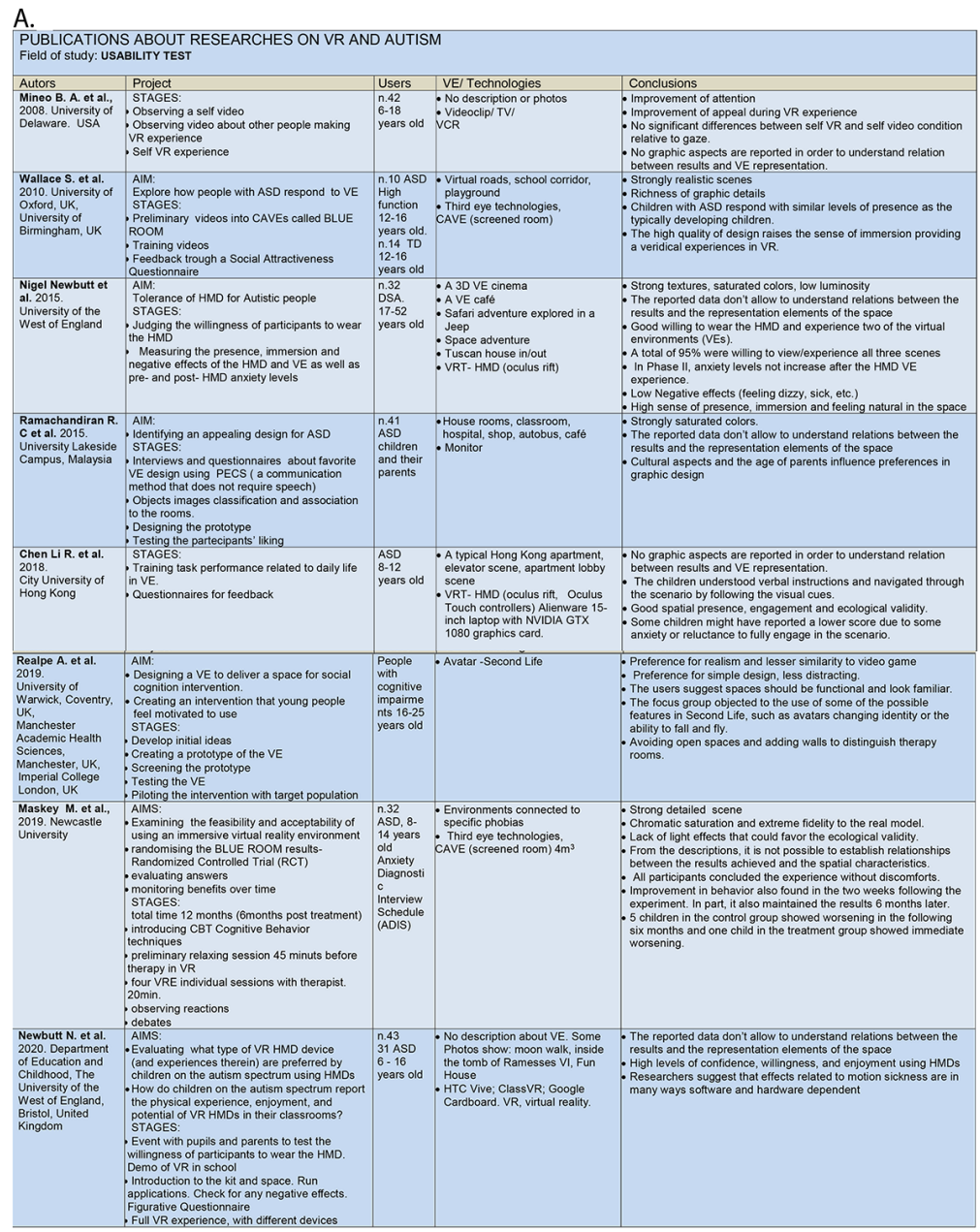


Fig. 8.Tab. B.: Researches about Life Skills.

Fig. 9. Tab. C.: Researches about Social Skills.
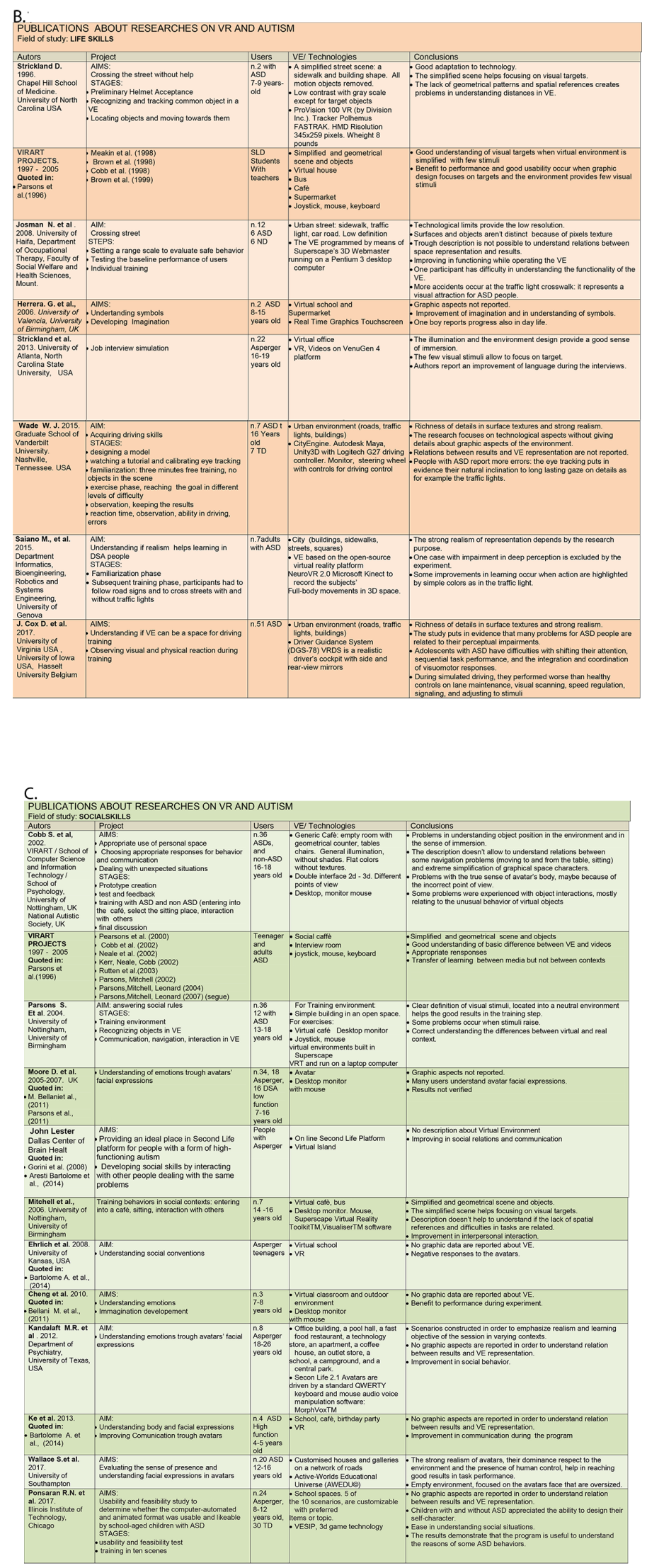
D

\begin{tabular}{|c|c|c|c|c|}
\hline $\begin{array}{l}\text { PUBLICATIONS } \\
\text { Field of study: SPE }\end{array}$ & $\begin{array}{l}\text { S ABOUT RESEARCHES ON VR } \\
\text { CIAL EDUCATION }\end{array}$ & AUT & & \\
\hline Autors & Project & Users & VE /Technologies & Conclusions \\
\hline $\begin{array}{l}\text { VIRART } \\
\text { PROJECTS. } 1997 \\
2005 . \\
\text { Virtual Reality } \\
\text { Application } \\
\text { Research Team } \\
\text { University of } \\
\text { Nottingham, UK }\end{array}$ & $\begin{array}{l}\text { (LEANGUAGE) } \\
\text { Brown et al. (1997) } \\
\text { Brown et al. (1997) } \\
\text { Brown,Cobb, Eastgate } \\
\text { (1995) }\end{array}$ & $\begin{array}{l}\text { SLD } \\
\text { Students } \\
\text { With } \\
\text { teachers }\end{array}$ & $\begin{array}{l}\text {-Urban environment, Sky slope, } \\
\text { virtual house, supermarket } \\
\text { GGraphical symbols } \\
\text { - joystick, mouse, keyboard }\end{array}$ & $\begin{array}{l}\text { - Simplified and geometrical scene and objects } \\
\text { The changing viewpoint can influence the Way finding. } \\
\text { Some children recognize and copy virtual objects, whereas others } \\
\text { have difficulties. Usability issues raises }\end{array}$ \\
\hline $\begin{array}{l}\text { Gorini et al. } 2008 \\
\text { Istituto Auxologico } \\
\text { Italiano, Milan, } \\
\text { Research Institute } \\
\text { Brain and } \\
\text { Behaviour, } \\
\text { Maastricht } \\
\text { University,Psycholo } \\
\text { gy Department, } \\
\text { Catholic University } \\
\text { of Milan }\end{array}$ & $\begin{array}{l}\text { AlMS: } \\
\text { - wsing motivation provided by virtual } \\
\text { worlds to teach users about how to } \\
\text { improve their living habits } \\
\text { - using the strength of virtual communities } \\
\text { to provide real-life insights } \\
\text { using the feeling of presence provided by } \\
\text { the virtual experience to practice both } \\
\text { emotional and relational management and } \\
\text { general decision }\end{array}$ & $\begin{array}{l}\text { People } \\
\text { with } \\
\text { psycholog } \\
\text { ical } \\
\text { disorders }\end{array}$ & $\begin{array}{l}\text { - Virtual island. } \\
\text { On line Second Life Platform }\end{array}$ & $\begin{array}{l}\text { - The graphic and visual aspects are not customized since they are } \\
\text { set by the platform Second Life. } \\
\text { - There are not descriptions concerning composition of the spaces } \\
\text { related to specific goals. } \\
\text { - Results are not reported. }\end{array}$ \\
\hline $\begin{array}{l}\text { Fornasari et al. } \\
\text { Italia. 2013. } \\
\text { Quoted in: } \\
\text { Aresti Bartolome et } \\
\text { al., (2014) }\end{array}$ & $\begin{array}{l}\text { STAGES: } \\
\text { Free exploration in VR } \\
\text { Exploration with a defined target }\end{array}$ & n.16 ASD & - Urban environment & $\begin{array}{l}\text { - No graphic aspects are reported in order to understand relation. } \\
\text { between results and VE representation. } \\
\text { - Children with ASD explore the VE faster than the TD children. }\end{array}$ \\
\hline $\begin{array}{l}\text { Kok N. et al. } 2014 . \\
\text { National Institute of } \\
\text { Education Nanyang } \\
\text { Technological } \\
\text { University }\end{array}$ & $\begin{array}{l}\text { AlM: } \\
\text { learning basic language concepts and skills }\end{array}$ & $\begin{array}{l}\text { Children } \\
\text { with ASD }\end{array}$ & $\begin{array}{l}\text { Dolphanarium } \\
\text {-VDAl,stereoscopic } \\
\text { lightweight 3-D glasses Kinect to } \\
\text { track positions } \\
\text { and movements }\end{array}$ & - No graphic aspects are reported neither results. \\
\hline $\begin{array}{l}\text { Naranjo C. A. et } \\
\text { al. 2018. } \\
\text { Universidad de las } \\
\text { Fuerzas Armadas } \\
\text { ESPE, Sangolqui- } \\
\text { Ecuador } \\
\text { Universidad } \\
\text { Técnica de } \\
\text { Ambato, Ambato- } \\
\text { Ecuador }\end{array}$ & $\begin{array}{l}\text { AIM: } \\
\text { Helping children with ASD to socialize and } \\
\text { contributing to interpersonal interaction } \\
\text { STAGES: } \\
\text { Avatar selection } \\
\text { Control of robot movements in order to } \\
\text { complete tasks defined by the teacher } \\
\text { Observing the changes made in VE }\end{array}$ & $\begin{array}{l}\text { children } \\
\text { DSA }\end{array}$ & $\begin{array}{l}\text { - Virtual castle, open spaces } \\
\text { HMD oculus rift, robot BIOLOID, } \\
\text { webcam, motion sensors Unity } 3 D \\
\text { platform }\end{array}$ & $\begin{array}{l}\text { No graphic aspects are reported in order to understand relation } \\
\text { between results and VE representation. } \\
\text { The results demonstrate the efficiency of the system under the } \\
\text { supervision of a teachertherapist, allowing the children to increase } \\
\text { their stimulation. }\end{array}$ \\
\hline
\end{tabular}

\section{References}

Argenton Alberto (2017). Arte e cognizione. Introduzione alla psicologia dell'arte. Milano: Raffaello Cortina Editore.

Arnheim Rudolf (1997). Arte e percezione visiva. Milano: Feltrinelli, 1997. (Edizione originale: Art and Visual Perception:A Psychology of the Creative Eye. By the Regens of the University of California, 1954).

Arnheim Rudolf (2019). La dinamica della forma architettonica. Sesto San Giovanni: MIMESIS edizioni. (Edizione originale: The Dinamics of Architectural Form).

Bartolome Nuria Aresti, Zapirain Begonya Garcia (20I4). Technologies as Support Tools for Persons with Autistic Spectrum Disorder: A Systematic Review. In Int.J. Environ. Res. Public Health II, 20 I4, pp.7767-7802

Bellani Marcella, Fornasari Livia, Chittaro L., Brambilla Paolo (20I I).Virtual reality in autism: state of the art. In Epidemiology and Psychiatric Sciences, no. 3, 201 I, Vol. 20, pp 235-238

Bogdashina Olga (20I5). Le percezioni sensoriali nell'autismo e nella sindrome di Asperger. Vignate (MI): Uovonero. (Edizione originale: Sensory Perceptual Issues in Autism And Asperger Syndrome. Different sensory Experiences - Different Perceptual World. London: Jessica Kingsley Publishers Ltd., 2003).

Bradley Ryan, Newbutt Nigel (20 I 8). Autism and virtual reality head-mounted displays: a state of the art systematic review. In Journal of Enabling Technologies, 10 September 2018

Cantelmi Tonino, Pensavalli Michela, Marzocca Massimiliano (20I5). Realtà Virtuale ed Aumentata: implicazioni teoriche ed applicative nei contesti educativi e nella clinica. In Modelli x la mente. (I), 20 I4, Vol.VI. pp. 9-I4.

Chen Li Richard (2018). A Case Study on Delivering Virtual Reality Learning for Children with Autism Spectrum Disorder Using Virtual Reality Headsets. In Proceedings of EDULEARN I 8 Conference. Palma Mallorca, Spain. 2nd-4th July 2018. pp. 728734.

Chia Noel Kok Hwee, Kee Norman Kiak Nam (20 I4). Application of Universal Design for Learning (Udl I) and Living (Udl2) in Virtual Dolphin-Assisted Intervention (Vdai) for Children with Autism. In The Journal of the International Association of Special Education, Spring 20 I4, No. I, Vol. I5, pp. 75-82.

Cobb Sue Valerie Gray, Beardon Luke, Eastgate Richard, Kerr Steven J. (2002). AppliedVirtual Environments to support learning of Social Interaction Skills in users with Asperger's Syndrome. In Digital Creativity, No. I, 2002, Vol. I 3, pp. I I-22

Cobb Sue Valerie Gray (2007).Virtual Environments Supporting Learning and Communication in Special Needs Education. In Top Lang Disorders. No. 3, 2007, Vol. 27, pp. 21 I-225.

Cox Daniel J., Brown Timothy, Ross Veerle, Moncrief Matthew, Schmitt Rose, Gaffney Gary, Reeve Ron (20 I7). Can Youth with Autism Spectrum Disorder Use Virtual Reality Driving Simulation Training to Evaluate and Improve Driving Performance? An Exploratory Study. In Journal of Autism and Developemental Disorders, 47, 2017, pp. 2544- 2555. 
Del Nord Romano (2010). Presentazione. In Giofrè Francesca (a cura di). Autismo protezione sociale e architettura. Firenze: Alinea editrice.

Florio Riccardo (2012). Sul disegno. Riflessioni sul disegno di architettura. Roma: Officina Edizioni.

Freeman Daniel, Reeve S. Jeffrey, Robinson A., Ehlers A., Clark D., Spanlang B., Slater M. (2017).Virtual reality in the assessment, understanding, and treatment of mental health disorders. In Psychological Medicine, 47, 20 I 7, pp. 2393-2400.

Giaconi Catia, Del Bianco Noemi (2018). In Azione: prove di inclusione. Milano: Open Access Franco Angeli.

Geraets Chris N.W., Veling Wim, Witlox Maartje, Staring Anton B.P, Suzy J.M.A. Matthijssen, Danielle Cath (2019). Virtual reality-based cognitive behavioural therapy for patients with generalized social anxiety disorder: a pilot study. In Behavioural and Cognitive Psychotherapy, 2019, pp. I-6.

Good Judith, Parsons Sarah, Yuill Nicola, Brosnan Mark (2016).Virtual reality and robots for autism: moving beyond the screen. In Journal of Assistive Technologies. December 2016.

Gorini Alessandra, Gaggioli Andrea, Vigna Cinzia, C., Riva Giuseppe (2008). A second life for Health: prospects for the use of 3-D virtual worlds in clinical psychology. In Journal of medical Internet research, iss. 3, e2 I, February 2008, vol. 10.

Gray Cobb Sue Valerie (2007). Virtual Environments Supporting Learning and Communication in Special Needs Education. In Top Lang Disorders. No. 3, 2007, Vol. 27, pp. 21 I-225

Herrera Gerardo, Jordan Rita, Vera Lucia (2006). Abstract concept and imagination teaching through Virtual Reality in people with AutismSpectrum Disorders. In Technology and Disability, IOS Press, 18, 2006, pp. I73- I80.

Josman Naomi, Weiss Patrice Lynne (2008). Effectiveness of Virtual Reality for Teaching Street-Crossing Skills to Children and Adolescents with Autism. In International Journal of Disability Development and Education. 7 (I), January 2008.

Kandalaft Michelle R., Didehbani Nyaz, Krawczyk Daniel C., Allen Tandra T., Chapman Sandra B., (2013). Virtual Reality Social Cognition Training for Young Adults with High-Functioning Autism. In Journal of Autism and Developmental Disorders. $43,2013$. pp. 33-44.

Maples-Keller Jessica L., Bunnell Brian E., Jin Kim-Sae, Rothbaum Barbara O. (2017). The use of virtual reality technology in the treatment of anxiety and other psychiatric disorders. In Harv Rev Psychiatry. 20 I 7, 25(3). pp. I03-I I 3.

Maskey Morag, Rodgers Jacqui, Grahame Victoria et. al (2019). A Randomised Controlled Feasibility Trial of Immersive Virtual Reality Treatment with Cognitive Behaviour Therapy for Specific Phobias in Young People with Autism Spectrum Disorder. In Journal of Autism and Developmental Disorders. 49. 2019. pp. 1912-1927.

Marcolli Attilio (197I). Teoria del Campo. Firenze: Sansoni

Mineo A. Beth, Ziegler William, Gill Susan, Donna Salkin (2008). Engagement with Electronic Screen Media Among Students with Autism Spectrum Disorders. In Springer Science+Business Media, 39, I 5 July 2008, pp. I 72 - 187.

Mitchell Peter, Parsons Sarah, Leonard Anne (2006). Using Virtual Environments for Teaching Social Understanding to 6 Adolescents with Autistic Spectrum Disorders. In Journal of Autism and Developemental Disorders. 37, 2007. pp. 589-600

Moore David, Cheng Yufang, McGrath Paul, J. Powell Norman (2005). Collaborative Virtual Environment Technology for People with Autism. In Focus Autism Other Dev Disabl., 20, 2005, pp. 23 I-243

Morganti Francesca, Riva Giuseppe (2005). Conoscenza, comunicazione e tecnologia. Aspetti Cognitivi della Realtà Virtuale. LED on line.

Mostafa Magda (2014). Architecture for autism: Autism Aspectss in School Design. In International Journal of Architectural Research, Issue I, March 2014, vol. 8. pp. I43-158.

Newbutt Nigel (20I5). The potential of virtual reality technologies for autistic people: A pilot study. In Network Autism, I5 December 2015 .

Newbutt Nigel, Sung Connie, Jen Kuo - Hung, J. Leahy Michael, Chun Lin - Chien, Tong Boyang (2016). Brief Report: A Pilot Study of the Use of a Virtual Reality Headset in Autism Populations. In Springer Science+Business Media, New York, 7 June 2016.

Newbutt, Nigel, Cobb Sue (2018). Towards a framework for implementation of virtual reality technologies in schools for autistic pupils. In P. Standen, S. Cobb, D. Brown, P. Gamito, \& K. Appiah (eds.). I 2th International Conference on Disability, Virtual Reality and Associated Technologies in Collaboration with Interactive Technologies and Games (ITAG). Sep 4, 2018 , pp. $268-272$.

Newbutt Nigel (20/8). Using virtual reality with autistic pupils: information and advance. In National Autistic Society, 19 November 2018.

Newbutt Nigel, Bradley Ryan, Conley Lian (2020). Using Virtual Reality Head-Mounted Displays in Schools with Autistic Children: Views, Experiences and Future Directions. In Cyberpsychology, Behavior, and Social Networking. Number I, 2020. Volume 23, pp. 23-33.

Ortiz Jessica S., Alvarez Marcelo Aníbal, Sánchez Jorge S., Andaluz Víctor H. (2017). Teaching Process for Children with Autism in Virtual Reality Environments. In ICETC 20 17, Barcelona, Spain. December 20-22, 20 I 7. pp. 4 I -45.

Parsons Sarah, Beardon Luke, Neale HR, Reynard Gail et al. (2000). Development of social skills amongst adults with Asperger's syndrome using virtual environments: the 'AS Interactive' project. In Sharkey P., Cesarani A., Pugnetti L., Rizzo A. (eds). Proceedings of the 3rd international conference on disability, virtual reality and associated technologies, ICDVRAT 2000. 23-25 September 2000. Alghero, Sardinia Italy, pp 163-170. 
Parsons Sarah, Cobb Sue (201 I). State-of-the-art of virtual reality technologies for children on the autism spectrum. In European Journal of Special Needs Education. 26 Aug 20I I, pp. 355-366.

Parsons Sarah, Mitchell Peter (2002). The potential of virtual reality in social skills training for people with autistic spectrum disorders. In Journal of Intellectual Disability Research. June 2002. Vol. 46, part. 5. pp. 430-443.

Parsons Sarah, Mitchell Peter, Leonard Anne (2004). The Use and Understanding of Virtual Environments by Adolescents with Autistic Spectrum Disorders. In Journal of Autism and Developmental Disorders, No. 4, August 2004, Vol. 34. pp. $449-466$

Parsons Thomas D., Rizzo Albert A. (2008). Affective outcomes of virtual reality exposure therapy for anxiety and specific phobias: A meta-analysis. In Journal of Behavior Therapy and Experimental Psychiatry. N.39, 2008, pp. 250-26I

Ponsaran Nicole Russo, McKown Clark, Johnson Jason, Russo Jaclyn, Crossman Jacob, Reife llana (20।8). Virtual Environment for Social Information Processing: Assessment of Children with and without Autism Spectrum Disorders. In Autism Research. I।, 20।8. pp. 305-317.

Rajendran Gnanathusharan (2012).Virtual Environmental and autism: a developmental Psycopathological approach. In Journal of Computer Assisted Learning. John Wiley \& Sons Ltd, UK 20 I3/29, pp. 334-347.

Ravasio Antonio (201 I). L'impiego dei sistemi di Realtà Virtuale in psicologia Clinica. In Scienze dell'interazione. Rivista di psicologia clinica e psicoterapia. I/201 I, Vol. 3, pp. 47-69.

Ramachandiran Chandra Reka, Jomhari Nazean, Maria Mahmud Malissa (20I5). Virtual reality based behavioural learning for autistic children. In Electronic Journal of e-Learning. Issue 5, 20I 5 Vol. I 3, pp. 357-365.

Realpe Alba, Elahi Farah, Bucci Sandra, Birchwood Max, Vlaev Ivo, Taylor David, Thompson Andrew (2019). Co designing a virtual world with people to deliver social cognition therapy in early psychosis. In Early intervention in Psychiatry, pp. I-7.

Rossi Daniele, Olivieri Alessandro (2019). First Person Shot: la prospettiva dinamica interattiva negli ambienti virtuali immersivi. In Belardi Paolo (a cura di). Riflessioni/Reflections. Atti del $41^{\circ}$ Convegno Internazionale dei Docenti delle Discipline della Rappresentazione. Perugia 19-2I Settembre 2019. Roma: Gangemi Editore, pp. 977-984.

Russell James (1994). Agency and early mental development. In Bermudez J.L., Marcel A.J., Eilan N. (eds.) The body and the self. The MIT Press Cambridge, Massachusetts

Saiano Mario, Pellegrino Laura, Casadio Maura, Summa Susanna et al. (2015). Natural interfaces and virtual environments for the acquisition of street crossing and path following skills in adults with Autism Spectrum Disorders: a feasibility study. In Journal of Neuroengineering and Rehabilitation, $12-17$.

Strickland Dorothy (1996). Brief Report:Two Case Studies Using Virtual Reality as a Learning Tool for Autistic Chidren. In Journal of Autism and Developemental Disorders, No. 6, 1996, Vol. 26, pp. 65 I - 659.

Strickland Dorothy (1997). Virtual Reality for the Treatment of Autism. In Virtual Reality in Neuro-Psychophysiology. los Press: Amsterdam

Strickland Dorothy (2013). JobTIPS: A Transition to Employment Program for Individuals with Autism Spectrum Disorders. In Journal of Autism and Developemental Disorders, 43, 2013. pp. 2472-2483.

Wade Joshua William, (2015). Design and Evaluation of a Virtual Reality Adaptive Driving Intervention Architecture (VADIA): Applications in Autism Spectrum Disorder. Thesis Submitted to the Faculty of the Graduate School of Vanderbilt University in partial fulfillment of the requirements for the degree of Master of Science in Computer Science. Nashville, Tennessee.

Wallace Simon, White Katie, White Kathy, Bailey Anthony, Parsons Sarah, Westbury Alice (20I0). Sense of presence and atypical social judgments in immersive virtual environments. In Autism Online First. 20 I 0. pp. I - I5.

Wallace Simon, Parsons Sarah, Bailey Anthony (2017). Self-reported sense of presence and responses to social stimuli by adolescents with autism spectrum disorder in a collaborative virtual reality environment. In Journal of Intellectual \& Developmental Disability, No. 2, 20 I7.Vol. 42. pp. I3I-I4I.

Weinel Jonathan, Cunningham Stuart, Pickles Jennifer (2018). Deep Subjectivity and Empathy in Virtual Reality: A Case Study on the Autism TMIVirtual Reality Experience. In Filimowicz M.,Tzankova V. (eds). New Directions in Third Wave Human-Computer Interaction. Cham: Springer, 03 July 20 I 8, Vol. I - Technologies. Human-Computer Interaction Series. pp. I 83-203.

Williams Donna (1994). Somebody Somewhere. London: Doubleday.

Klinger Evelyne, Bouchard Stéphane, Légeron P. et al. (2005). Virtual Reality Therapy Versus Cognitive Behavior Therapy for Social Phobia: A Preliminary Controlled Study. In Cyberpsychology \& Behavior, Number I, 2005, Mary Ann Liebert, Inc., Volume 8. pp. 76-88.

\section{Author}

Anna Lisa Pecora, University of Napoli “Federico II”, annalisa.pecora@unina.it

To cite this chapter. Pecora Anna Lisa (2020). Virtual Environment for Autism. Drawing Space for Connection and Inclusion: an Open Debate. In Arena A., Arena M., Brandolino R.G., Colistra D., Ginex G., Mediati D., Nucifora S., Raffa P. (a cura di). Connettere. Un disegno per annodare e tessere. Atti del $42^{\circ}$ Convegno Internazionale dei Docenti delle Discipline della Rappresentazione/Connecting. Drawing for weaving relationships. Proceedings of the 42th International Conference of Representation Disciplines Teachers. Milano: FrancoAngeli, pp. 257I-258I. 